\title{
Comparison of Nutritive Values and in vitro Degradability of Steam Treated Rice Straw with Chinese Wild Rye and Alfalfa
}

\author{
Muhammad Naeem ${ }^{1,2}$, Nasir Rajput ${ }^{1,2}$, Sher Ali ${ }^{3}$, Asmatullah Kaka², \\ Dildar Hussain Kalhoro ${ }^{2}$, Mehvish Rajput ${ }^{2}$ and Tian Wang,* \\ ${ }^{1}$ College of Animal Science and Technology, Nanjing Agricultural University, \\ Nanjing 210095, China \\ ${ }^{2}$ Faculty of Animal Husbandry and Veterinary Science, Sindh Agriculture University, \\ Tandojam, Pakistan \\ ${ }^{3}$ Department of Meat Science and Technology, University of Veterinary and Animal \\ Science, Lahore, Pakistan
}

\begin{abstract}
A B S T RA C T
The study was conducted to compare the chemical composition and in vitro degradability of steam treated rice straw, alfalfa hay $(\mathrm{AH})$ and Chinese wild rye (CWR).The rice strawswere treated with steam pressure, i.e. TRS-I (exposed to $15.5 \mathrm{kgf} / \mathrm{cm}^{2}$ steam pressure for $90 \mathrm{sec}$ ), TRS-II (exposed to $15.5 \mathrm{kgf} / \mathrm{cm}^{2}$ steam pressure for $120 \mathrm{sec}$ ). The results regarding chemical composition revealed that steam treated straw had higher $(\mathrm{P}<0.05)$ dry matter $(\mathrm{DM})$, ash and acid detergent fiber $(\mathrm{ADF})$ contents; lower $(\mathrm{P}<0.05)$ organic ma ter $(\mathrm{OM})$ than $\mathrm{AH}$ and $\mathrm{CWR}$, the ether extract (EE) were higher and neutral detergent fiber (NDF) were lower $(\mathrm{P}<0.05)$ in $\mathrm{AH}$ and TRS-II, while the crude protein $(\mathrm{CP})$ were higher and acid detergent lignin $(\mathrm{ADL})$ were lower $(\mathrm{P}<0.05)$ in $\mathrm{AH}$ than other groups. The concentration of acetate, butyrate and iso-butyrate were almost similar in TRS-II, AH and CWR; valeric and iso-valericwere lower $(\mathrm{P}<0.05)$ in CWR and TRS-I than AH and TRS-II, while the propionate and total VFA were higher in AH but similar in CWR and treated rice straw. The in vitro degradibility of DM, OM and NDF were significantly higher for AH and TRS-II while, ADF was higher for AH. Steam treated straws showed increased $(\mathrm{P}>0.05) \mathrm{pH}$ and $\mathrm{NH}_{3}-\mathrm{N}(\mathrm{P}<0.05)$, while total gas production was higher in AH and TRS-II than other groups. These findings suggest that steam treated straw had better nutrients values and degradibility over Chinese wild rye, so it could be used as forage for ruminants.
\end{abstract}

Article Information
Received 02 January 2017
Revised 28 May 2018
Accepted 01 September 2018
Available online 27 March 2021
Authors' Contribution
MN and TW conceived and designed
the experiments. MN, NR and SA
performed the experiments. MN and
AK wrote the paper. DHK and MR
checked and formatted the article.
Key words
Microsatellite loci, Neosalanx Alfalfa,
Chinese wild rye, Rice straw, Steam
treatment.

\section{INTRODUCTION}

G lobally livestock species are reared to endeavor human demand of animal protein. Increasing human population and high demand of animal protein can only be overcome by increasing livestock production (Akinfemi et al., 2010). Several roughages such as Chinese wild rye (Leymus chinesis) are widely used in ruminant's food to fulfill the demand, but due to low crude protein and energy contents, additional source of protein and energy is required to achieve the maximum animal production (Zhu et al., 2013). While, establishing a good stand of high quality forages such as alfalfa (Medicago sativa $\mathrm{L}$.) is challenging as the ideal alfalfa soil is deep and well-drained (Lacefield, 2013). Simultaneously, decreasing land for crop cultivation due to constrained by human population and urbanization the animal production is facing more challenges such as

\footnotetext{
Corresponding author: tianwangnaju@163.com 0030-9923/2021/0003-1053 \$ 9.00/0

Copyright 2021 Zoological Society of Pakistan
}

increased production cost due to decreased availability of feed (Devendra and Leng, 2011; Trach, 1998). In this scenario, there is a widespread interest to search and or to utilize non-conventional feed ingredients for livestock.

On the other hand global paddy production forecast now stands at 730.2 million tons for the year 2013 (FAO, 2013). The average ratio of rice grain: rice husk:rice straw is 1: $0.25: 1.25$, which reflects that there is an ample quantity of agricultural by-products such as straw of rice are available, out of which a huge quantity is burned in the field by the growers,causing serious pollution complications (Haefele et al., 2011; Liu and Ørskov, 2000). Full use of crop residues as feeds for ruminant animals is of strategic importance in the developing countries where forage resources of good qualityare in short supply. Therefore, effective utilization of the available feed resources crop residue based diets become more important and necessary step to alleviate the problem and it is suggested that attention must be shifted to the use of these available crop residues as a feed resource (Getinet and Yoseph, 2014; Devendra and Leng, 2011). 
As rice straw is poorly fermented, it has lower rates of disappearance in the rumen (Sarnklong et al., 2010) therefore, feeding only rice straw does not provide enough nutrients to the ruminants to maintain high production levels due to the low nutritive value of this highly lignified material. This issue needs an attention to develop an efficient method for hydrolyzing fibrous materials in rice straw (Liu and Ørskov, 2000) and to utilize it as livestock feed. Steam explosion treatment has shown significant potential as a cost-effective pre-treatment of lignocellulosics (Castro, 1994). It has been shown to increase energy availability by solubilization of cellulose and hemicellulose and/or by freeing digestible materials from lignin or silica (Liu and Ørskov, 2000).

To the best of our knowledge, almost no study has been conducted to compare steam treated rice straw with Chinese wild rye grass or alfalfa hay as an additional forage source for ruminants. Hence, the aim of this study was to evaluate the effectiveness of the steam explosion treatment to enhance nutritive value of rice straw and its use as an unconventional feed source.

\section{MATERIALS AND METHODS}

\section{Samples preparation and steam explosion treatments}

Rice straw was cut into $3-5 \mathrm{~cm}$ length and treated with steam at steam pressures $15.5 \mathrm{kgf} / \mathrm{cm}^{2}$ for 90 seconds (TRS-I) and 120 seconds (TRS-II), respectively, by using a steam explosion machine, dried and stored according to the method described by Li et al. (2013) for further analysis. Chinese wild rye and alfalfa samples were also prepared in accordance with the experimental design.

\section{Chemical analysis of sample grasses}

Samples were forced air dried in oven at $65^{\circ} \mathrm{C}$ for $48 \mathrm{~h}$ for determination of dry matter (DM), organic matter $(\mathrm{OM})$ and ash contents of the samples were determined according to the methods described by AOAC (2000). The neutral detergent fiber (NDF) and acid detergent fiber (ADF) contents were determined by using an Ankom 200 fiber analyzer following the user's instructions (Ankom Technology, 2011). Acid detergent lignin (ADL) contents were determined by using acid detergent lignin beakers method (Ankom Technology, 2005). The ether extract (EE) of samples was extracted with methanol by using soxhlet apparatus. Crude protein (CP) was determined by Kjeldahl method with Kjeltec 2300 apparatus of Foss USA.

\section{In vitro fermentation}

The rumen fluid was collected before the morning feeding from sixruminally-fistulated Xuhuaigoats under a continuous flow of $\mathrm{CO}_{2}$ thoroughly mixed and strained through four layers of muslin cloth into a pre-warmed insulated thermos. Thedonor goats were offereddiet with an equal ratio of forage and concentrate (Table I). The diet was provided twice a day at 9:00 am and 05:00 pm, the fresh water was made available $24 \mathrm{~h}$.

Table I.- Ingredient (g/kg) and chemical composition (\%) of donor goats diet.

\begin{tabular}{lc}
\hline Item & \\
\hline Ingredients (g/kg) & \\
Maize & 365.25 \\
Soya Bean & 105.35 \\
Stone powder & 7.15 \\
$\mathrm{Ca}\left(\mathrm{HPO}_{4}\right)_{2}$ & 11.13 \\
Salt & 5.00 \\
Premix & 6.12 \\
Rice Straw & 500.00 \\
Chemical composition of feed $\mathbf{( \% )}$ & \\
Crude Protein & 12.50 \\
NDF & 43.80 \\
Ca & 0.73 \\
P & 0.30 \\
\hline
\end{tabular}

NDF, neutral detergent fiber

In vitro degradibility of $\mathrm{DM}, \mathrm{OM}, \mathrm{NDF}, \mathrm{ADF}$ and gas production (IVGP) were determined accordingtoTilley and Terry (1963). The grass samples $(2.5 \pm 0.1 \mathrm{~g})$ were weighed and put into in vitro fermentation bottles. The bottles were filled with $50 \mathrm{ml}$ of medium consisting of 1:4 ratios of rumen fluid and artificial saliva, which was prepared according to the McDougall (1948). The bottles were sealedwith a rubber stopper equipped with Bunsen valve for gas escape, all bottles were incubated at $39^{\circ} \mathrm{C}$ up to $48 \mathrm{~h}$. At $0,2,4,8,12,24,36$ and $48 \mathrm{~h}$ of incubation, five bottles from each treatment were collected and unsealed; gas volume was measured by reading and recording the amount of gas volume after incubation by using a $100 \mathrm{ml}$ glass syringe connected to the incubation bottle with a needle, $\mathrm{pH}$ and gas volume were recorded immediately. The fluid collected by filtering through nylon bags into tubes and stored at $-20^{\circ} \mathrm{C}$ for volatile fatty acids (VFAs) and $\mathrm{NH}_{3}-\mathrm{N}$ analysis. The sample residues in the bags were flushed with tap water until it became colorless, dried at 65 ${ }^{\circ} \mathrm{C}$ for $24 \mathrm{~h}$ and stored for further analysis.

\section{$\mathrm{NH}_{3}-\mathrm{N}$ determination}

After centrifugation of fermented samples; $1 \mathrm{ml}$ supernatant was added to $9 \mathrm{ml}$ distilled water, thoroughly mixed one millilitre of this mixture added to $0.04 \mathrm{ml}$ of Nesseler reagent and $3.6 \mathrm{ml}$ of distilled water. In order to know the linear relationship between varying concentration 
of $\mathrm{NH}_{4} \mathrm{Cl}$ stander solution and color intensity produced by nesselerization a stander curve was made by using tubes of different concentrations of stander solution as described by Ali et al. (2008), the color intensity was measured at $540 \mathrm{~nm}$ after setting it at 0 absorbance with blank. The $\mathrm{NH}_{3}-\mathrm{N}$ concentration was calculated as below:

$\mathrm{NH}_{3}-\mathrm{N}(\mathrm{mg} / 100 \mathrm{ml})=\frac{\text { Absorbance of samples }}{\text { Absorbance of standard }} \times$ conc. of standard

Gas chromatography (Agilent Technologies 7890A, GC system) was used to determine acetate, propionate, butyrate, iso-butyrate, valeric and iso-valeric concentrations as per the method of Bjorkman and Forslund (1986), with some modification. A $30 \mathrm{~m} \times 0.25$ $\mathrm{mm}$ i.d. fused silica capillary column with a $0.25 \mu \mathrm{m}$ film was used (Catalog No: 24107, Supelco). The nitrogen, hydrogen and air were used as a carrier, fuel combustionsupporting gases, respectively. The temperature of the column, injector and the flame ionization detector were $120^{\circ} \mathrm{C}, 180{ }^{\circ} \mathrm{C}$ and $210^{\circ} \mathrm{C}$, respectively.

Table II.- Chemical composition (g/kg DM) of alfalfa hay, Chinese wild rye and steam treated rice straws.

\begin{tabular}{lcccc}
\hline Item & \multicolumn{4}{c}{ Treatment } \\
\cline { 2 - 5 } & AH & CWR & TRS-I & TRS-II \\
\hline DM $(\mathrm{g} / \mathrm{kg})$ & $893.4 \pm 10.2^{\mathrm{c}}$ & $905.2 \pm 12.5^{\mathrm{b}}$ & $911.9 \pm 11.1^{\mathrm{b}}$ & $921.6 \pm 12.2^{\mathrm{a}}$ \\
$\mathrm{OM}$ & $932.9 \pm 10.9^{\mathrm{a}}$ & $945.6 \pm 15.8^{\mathrm{a}}$ & $897.8 \pm 17.5^{\mathrm{b}}$ & $864.1 \pm 15.3^{\mathrm{b}}$ \\
$\mathrm{Ash}$ & $67.1 \pm 1.9^{\mathrm{b}}$ & $54.4 \pm 3.8^{\mathrm{b}}$ & $102.2 \pm 4.6^{\mathrm{a}}$ & $135.9 \pm 5.6^{\mathrm{a}}$ \\
$\mathrm{EE}$ & $22.6 \pm 1.7^{\mathrm{c}}$ & $34.47 \pm 1.1^{\mathrm{a}}$ & $28.8 \pm 1.0^{\mathrm{b}}$ & $35.8 \pm 1.3^{\mathrm{a}}$ \\
$\mathrm{CP}$ & $144.6 \pm 8.1^{\mathrm{a}}$ & $44.9 \pm 1.1^{\mathrm{c}}$ & $53.55 \pm 2.1^{\mathrm{b}}$ & $54.2 \pm 2.5^{\mathrm{b}}$ \\
$\mathrm{NDF}$ & $605.8 \pm 13.4^{\mathrm{b}}$ & $757.2 \pm 23.2^{\mathrm{a}}$ & $783.2 \pm 17.2^{\mathrm{a}}$ & $671.7 \pm 19.6^{\mathrm{b}}$ \\
$\mathrm{ADF}$ & $375.6 \pm 12.6^{\mathrm{b}}$ & $415.9 \pm 13.1^{\mathrm{b}}$ & $517.8 \pm 18.9^{\mathrm{a}}$ & $461.6 \pm 18.0^{\mathrm{a}}$ \\
$\mathrm{ADL}$ & $58.3 \pm 2.4^{\mathrm{b}}$ & $63.7 \pm 3.1^{\mathrm{a}}$ & $64.3 \pm 2.2^{\mathrm{a}}$ & $61.8 \pm 4.1^{\mathrm{a}}$ \\
\hline
\end{tabular}

AH, alfalfa hay; CWR, Chinese wild rye; TRS-I, rice straw treated with steam explosion at $15.5 \mathrm{kgf} / \mathrm{cm}^{2}$ for $90 \mathrm{sec}$; TRS-II, rice straw treated with steam explosion at $15.5 \mathrm{kgf} / \mathrm{cm}^{2}$ for $120 \mathrm{sec}$. DM, dry matter; $\mathrm{OM}$, organic matter; $\mathrm{EE}$, ether extract; $\mathrm{CP}$, crude protein; NDF, neutral detergent fiber; ADF, acid detergent fiber; ADL, acid detergent lingnin. abc Mean values in the same row that do not share a common letter are significantly different $(\mathrm{P}<0.05) ; \mathrm{n}=5$. Values are presented as mean $\pm \mathrm{SE}$.

\section{Statistical analysis}

The data were analyzed by ONE-way ANOVA (SAS 9.0, SAS Institute Inc., Cary, NC). Five replicates were used for determination of chemical composition and other parameters of in vitro degradibility and results were presented as mean \pm SEM. Significant differences among means were evaluated using Tukey's comparison test at $(\mathrm{P}<0.05)$.

\section{RESULTS}

\section{Chemical composition}

Results regarding chemical composition of rice straw treated with steam (TRS-I and TRS-II), Chinese wild rye (Leymus chinesis) (CWR) and alfalfa hay (AH) are presented in Table II. DM were higher $(\mathrm{P}<0.05)$ for TRS-II than that of AH, CWR and TRS-I. While higher $(\mathrm{P}<0.05)$ organic matter (OM) for AH and CWR was recorded than that of treated rice straw (TRS-I and TRS-II). The ash and ADF contents were significantly high TRS-II and TRS-I, as compared to $\mathrm{AH}$ and CWR. Crude protein (CP) contents were significantly higher and ADL were lower for AH than that of CWR, TRS-I and TRS-II. Ether Extract (EE) was significantly higher for the CWR and TRS-II as compare with AH and TRS-I. Significantly low NDF contents for AH and for TRS-II were recorded than that of CWR and TRS-I.

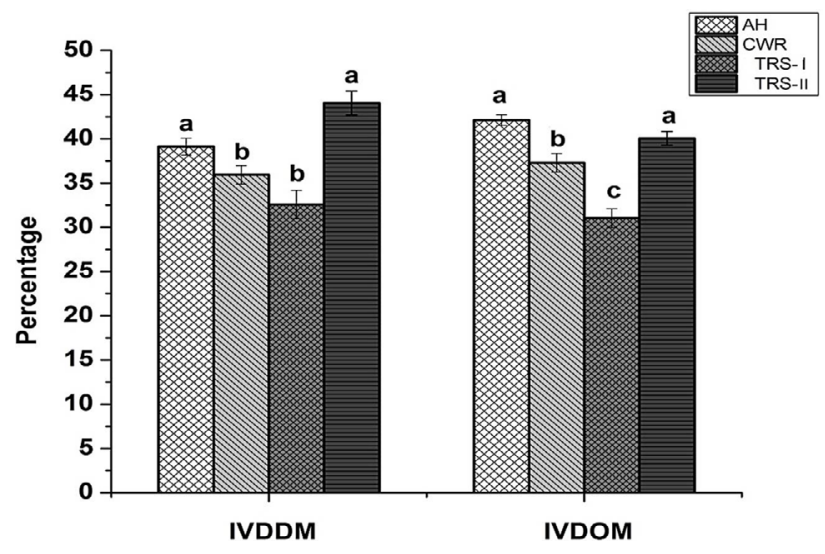

Fig. 1. In vitro dry matter digestibility (IVDMD \%) and organic matter digestibility (IVOMD \%) of steam treated rice straws, alfalfa hay and Chinese wild rye. $\mathrm{AH}$, alfalfa hay; CWR, Chinese wild rye; TRS-I, rice straw treated with steam explosion at $15.5 \mathrm{kgf} / \mathrm{cm}^{2}$ for $90 \mathrm{sec}$; TRS-II, rice straw treated with steam explosion at $15.5 \mathrm{kgf} / \mathrm{cm}^{2}$ for $120 \mathrm{sec}$. abc Mean values that do not share a common letter are significantly different $(\mathrm{P}<0.05) ; \mathrm{n}=5$. Values are presented as mean $\pm \mathrm{SE}$.

In vitro degradibility

The in vitro dry matter degradibility (IVDMD) was higher by $8.90 \%$ and $20.11 \%$ for $\mathrm{AH}$ and $22.57 \%$ and $35.19 \%$ for TRS-II as compared with CWR and TRS-I, respectively Similarly the in vitro organic matter degradibility (IVDOM) was significantly higher by $13.01 \%$ and $35.77 \%$ and $7.42 \%$ and $29.05 \%$ for $\mathrm{AH}$ and TRS-II than that of CWR and TRS-I, respectively (Fig. 1). The DNDF was higher $(\mathrm{P}<0.05)$ by $21.52 \%$ and $21.15 \%$ in AH and $12.17 \%$ and $11.84 \%$ in TRS-II than CWR and TRS-I, respectively. Whereas, DADF were significantly higher in AH by $32.20 \%, 87.01 \%$ and $16.06 \%$ than that of CWR, TRS-I and TRS-II, respectively (Fig. 2).

The results regarding cumulative gas production, $\mathrm{pH}$ and $\mathrm{NH}_{3}-\mathrm{N}$ are presented in Figure 3, gas production was 
significantly higher for TRS-II and AH, than that of TRS-I and CWR, respectively. $\mathrm{NH}_{3}-\mathrm{N}$ was lower $(\mathrm{P}<0.05)$ in $\mathrm{AH}$ as compared with CWR, TRS-I and TRS-II, respectively. The $\mathrm{pH}$ was not differ $(\mathrm{P}>0.05)$ among the treated straw and other groups.

\section{Volatile fatty acids}

Individual and total VFA concentrations are presented in Table III. Higher $(\mathrm{P}<0.05)$ total volatile $\mathrm{AH}$, alfalfa hay; CWR, Chinese wild rye; TRS-I, rice straw treated with steam explosion at $15.5 \mathrm{kgf} / \mathrm{cm}^{2}$ for $90 \mathrm{sec}$; TRS-II, rice straw treated with steam explosion at $15.5 \mathrm{kgf} / \mathrm{cm}^{2}$ for 120 sec. ${ }^{\text {abc }}$ Mean values in the same row that do not share a common letter are significantly different $(\mathrm{P}<0.05) ; \mathrm{n}=5$. Values are presented as mean \pm SE.fatty acids (TVFAs) concentration was recorded for $\mathrm{AH}$ group followed by TRS-II, CWR and TRS-I, TVFAs were 9.15\%, 13.48\% and $23.71 \%$ higher in AH than that of TRS-II, CWR and TRS-I, respectively. Similarly propionate concentration was higher $(\mathrm{P}<0.05)$ by $11.04 \%, 18.47 \%$ and $20.43 \%$ while, valeric acid was higher by $39.09 \%, 73.86 \%$ and $109.59 \%$ and $i s o$-valeric acid was higher by $36.90 \%, 161.36 \%$ and $202.63 \%$ in AH as compared with TRS-II, CWR and TRS-I, respectively. Steam treated straws had lower $(\mathrm{P}<0.05)$ butyrate concentration by $38.06 \%$ and $26.00 \%$ for TRS-I and $27.68 \%$ and $24.98 \%$ for TRS-II as compared with AH and CWR, respectively. The concentrations of acetate and iso-butyrate were significantly higher by $10.45 \%$ and $20.56 \%$ for $\mathrm{AH}$ and $5.50 \%$ and $15.16 \%$ for TRS-II, than that of CWR and TRS-I, respectively.

\section{DISCUSSION}

Steam and pressure treatments are known to disrupt lignocellulosics, which improved utilization of cell wall polysaccharides by cell-free enzymes and rumen microbes (Castro and Machado, 1990). Lignin transformation and hemicellulose solubilisation to free the carbohydrates from the lignin and by breaking the chemical and physical bonds are the main advantages of steam explosion treatment (Viola et al., 2008; Brodeur et al., 2011). The extent of cell wall solubility of steam treated straw was found to positively

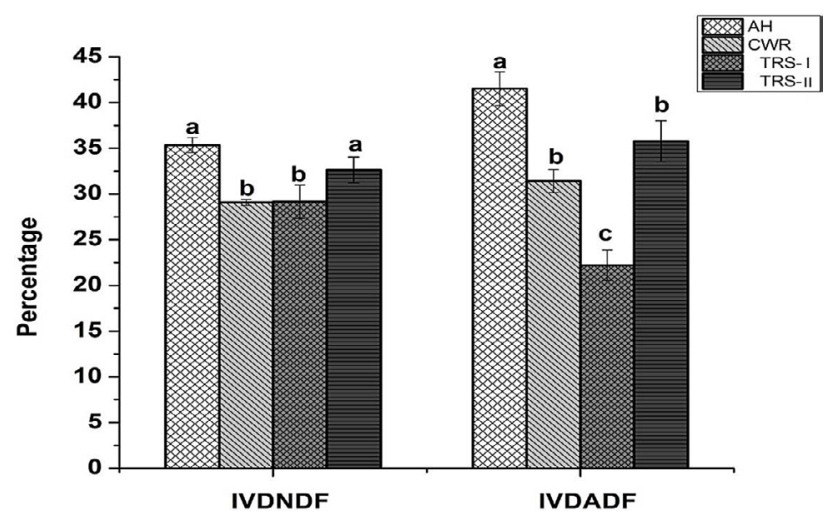

Fig. 2. In vitro DNDF (\%) and DADF (\%) steam treated rice straws, alfalfa hay and Chinese wild rye. For abbreviations and statistical details, see Figure 1.

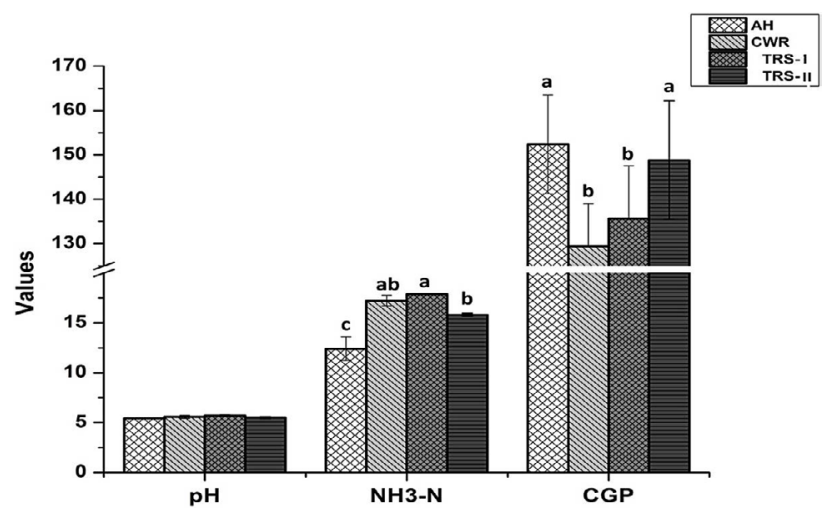

Fig. 3. In vitro cumulative gas production (CGP), $\mathrm{pH}$ and $\mathrm{NH}_{3}-\mathrm{N}(\mathrm{mg} / 100 \mathrm{ml})$ concentrations of steam treated rice straws, alfalfa hay and Chinese wild rye. For abbreviations and statistical details, see Figure 1

Table III.- In vitro volatile fatty acid production ( $\mathrm{mmol} / \mathrm{l})$ of alfalfa hay, Chinese wild rye and steam treated rice straws.

\begin{tabular}{|c|c|c|c|c|}
\hline \multirow[t]{2}{*}{ Item } & \multicolumn{4}{|c|}{ Treatment } \\
\hline & $\mathbf{A H}$ & CWR & TRS-I & TRS-II \\
\hline Acetate & $79.29 \pm 3.52^{\mathrm{a}}$ & $71.79 \pm 2.83^{b}$ & $65.77 \pm 2.57^{\mathrm{c}}$ & $75.74 \pm 3.67^{\mathrm{ab}}$ \\
\hline Propionate & $47.28 \pm 1.97^{\mathrm{a}}$ & $39.91 \pm 1.14^{\mathrm{b}}$ & $39.26 \pm 1.89^{\mathrm{b}}$ & $42.58 \pm 1.25^{\mathrm{b}}$ \\
\hline Butyrate & $13.24 \pm 0.42^{\mathrm{a}}$ & $12.96 \pm 0.61^{\mathrm{a}}$ & $9.59 \pm 0.39^{\mathrm{b}}$ & $10.37 \pm 0.45^{\mathrm{ab}}$ \\
\hline Iso-butyrate & $2.39 \pm 0.05^{\mathrm{a}}$ & $1.68 \pm 0.09^{b}$ & $1.36 \pm 0.07^{\mathrm{c}}$ & $2.08 \pm 0.08^{\mathrm{ab}}$ \\
\hline Valeric acid & $1.53 \pm 0.10^{\mathrm{a}}$ & $0.88 \pm 0.03^{\mathrm{c}}$ & $0.73 \pm 0.05^{\mathrm{c}}$ & $1.10 \pm 0.02^{\mathrm{b}}$ \\
\hline Iso-valeric & $1.15 \pm 0.05^{\mathrm{a}}$ & $0.44 \pm 0.03^{\mathrm{c}}$ & $0.38 \pm 0.02^{\mathrm{c}}$ & $0.84 \pm 0.06^{\mathrm{b}}$ \\
\hline Total VFA & $144.87 \pm 5.24^{\mathrm{a}}$ & $127.66 \pm 3.56^{\mathrm{b}}$ & $117.10 \pm 4.75^{\mathrm{c}}$ & $132.72 \pm 4.49^{b}$ \\
\hline
\end{tabular}

For abbreviations, see Table II.

VFA, volatile fatty acid 
respond to the pressure of steam conditions (Kim et al., 2005). The lower OM contents were observed in steam treated rice straws than that of Alfalfa hay (AH) and Chinese wild rye (CWR), these results are in agreement with Kim et al. (2005) who reported that OM values were decreased with increasing of pressure at the same time. While, Chaji et al. (2010) reported a declining trend for NDF content and a rising trend for ADF contents with the increasing steam pressure and time of treatment. In addition steam explosion process increased the susceptibility of cellulose to enzymatic hydrolysis and cellulose will be more accessible for rumen microbial enzymes, similarly we observed that the steam treated rice straw with 15.5 $\mathrm{kgf} / \mathrm{cm}^{2}$ for $120 \mathrm{sec}$, (TRS-II) had lower, but almost similar NDF as Alfalfa hay (AH) while, at the same pressure with lower time $\left(15.5 \mathrm{kgf} / \mathrm{cm}^{2}\right.$ for $\left.90 \mathrm{sec}\right)$ the NDF contents were higher than TRS-II and AH but similar as found in Chinese wild rye (CWR). However, the ADF contents were higher in both steam treated straws as compared to $\mathrm{AH}$ and $\mathrm{CWR}$. $\mathrm{NH}_{3}-\mathrm{N}$ concentration of fermented liquid was similar in TRS-II and AH, but lower that other treatments, enhanced utilization of $\mathrm{NH}_{3}-\mathrm{N}$ by rumen bacteria suggest that amino acid from protein were less available for deamination into microbial cell (McMahon et al., 1999). Cumulative gas production was higher in AH and TRS-II than CWR and TRS-I, researchers have reported that application of steam treatment increased the gas production parameters (Chaji et al., 2010) similar trend was also recorded in our previous work (Naeem et al., 2014) that steam treated straw had higher cumulative gas production as compared to the untreated one.

The in vitro dry matter (DM), organic matter (OM) and NDF degradibility for TRS-II and AH were similar but higher than TRS-I and CWR, which is in agreement of other work who reported that $\mathrm{AH}$ had higher degradation than CWR (Zhu et al., 2013) and steam treatment of rice straw at $15.5 \mathrm{kgf} / \mathrm{cm}^{2}$ for $120 \mathrm{sec}$ may cause partial or complete hydrolysis of hemicellulose fractions into more soluble components hence increased the digestibility (Toussaint et al., 1991). While the in vitro ADF degradibility of treated straws was lower than AH and CWR which may be a cause of lignin chemical complex formed with cellulose (Han, 1975). Kim et al. (2005) reported higher concentrations of VFAs in rice treated with $16 \mathrm{kgf} / \mathrm{cm}^{2}$ likewise we observed that the fermented liquid concentration of acetate, propionate, butyrate, iso-butyrate, valeric, iso-valeric concentrations and total volatile fatty acids (TVFAs) were higher in AH followed by TRS-II and CWR, respectively. Although the nutritive value of treated straw in this study was found lower than alfalfa hay but there was significant variation in chemical composition and degradibility of steam treated straw at $15.5 \mathrm{kgf} / \mathrm{cm}^{2}$ for $120 \mathrm{sec}$ (TRSII) over CWR, similar finding were reported by Liu et al. (1999) and FAO (1998) that the digestibility of steam treated straw was comparable to the hay of medium quality.

Although the nutritive value of treated straw was lower than alfalfa hay, but rice straw treated with steam at $15.5 \mathrm{kgf} / \mathrm{cm}^{2}$ for 120 , had better nutrient values and digestibility over Chinese wild rye (Leymus chinesis), so it could be used as a forage source for ruminant nutrition.

\section{ACKNOWLEDGEMENT}

This work was supported by the Jiangsu Provincial Science and Technology Support Program: crop straw feed, efficient use of technology, project number: BE2010356, and partially by Sindh Agriculture University Tandojam, Pakistan, under the HEC approved project. Authors are also grateful to Prof. Gao Xiang, College of Engineering, Nanjing Agricultural University Nanjing, China, for designing steam explosion machine and providing technical facilities for steam explosion treatment.

\section{Statement of conflict of interest}

The authors declare that there is no conflict of interest regarding publication of this article

\section{REFERENCES}

Akinfemi, A., Jonathan, S.G. and Adu, A.O., 2010. Improving the nutritive value of millet Stover using biological treatment. Libyan Agric. Res. Centre J. Int., 1: 195-201.

Ali, C.S., Khaliq, T., Sarwar, M., Javaid, A., Shahzad, M.A., Nisa, M. and Zakir, S., 2008. Effect of various non-protein nitrogen sources on in vitro dry matter digestibility, ammonia production, microbial growth and $\mathrm{pH}$ changes by rumen bacteria. Pak. Vet. J., 28: 25-30.

AOAC, 2000. Official method of analysis 934.01, $17^{\text {th }}$ edition. Association of Official Analytical. Chemists, Inc., Maryland, USA.

Ankom Technology, 2011. Method for determining neutral and acid detergent fiber. Ankom Technology, Macedon, NY.

Ankom Technology, 2005. Method for determining acid detergent lignin in beakers. Ankom Technology, Macedon, NY.

Bjorkman, C. and Forslund, K., 1986. Volatile fatty acids in adult and young ruminants: An evaluation of a gas chromatographic method. J. Dairy Sci., 69: 998-1003. https://doi.org/10.3168/jds.S00220302(86)80494-5

Brodeur, G., Elizabeth, Y.K., Badal, J., Collier, K., Ramachandran, B. and Ramakrishnan, S., 2011. Chemical and physicochemical pretreatment of lignocellulosic biomass: A review. Enzyme 
Res., 2011: Article ID 787532. https://doi. org/10.4061/2011/787532

Castro, F.B., 1994. The use of steam treatment to upgrade lignocellulosic materials for animal feed. $\mathrm{PhD}$. thesis, University of Aberdeen, Scotland, UK, pp. 167-172.

Castro, F.B. and Machado, P.F., 1990. Feeding value of steam sugar cane bagasse in ruminant ration. Livest. Res. Rural Dev., 2: 1-6.

Chaji, M., Mohammadabadi, T., Mamouei, M. and Tabatabaei, S., 2010. The effect of processing with high steam and sodium hydroxide on nutritive value of sugarcane pith by in vitro gas production. J. Anim. Vet. Adv., 9: 1015-1018. https://doi. org/10.3923/javaa.2010.1015.1018

Devendra, C. and Leng, R.A., 2011. Feed resources for animals in Asia: Issues, strategies for use, intensification and integration for increased productivity: A review. Asian-Aust. J. Anim. Sci., 24: 303-321.

Getinet, Y. and Mekasha, Y., 2014. Effect of feeding concentrate, dried khat (Catha edulis) left over or their mixtures on feed intake, digestibility and body weight change of Hararghe highland goats fed basal diet of natural grass hay. J. Anim. Pl. Sci., 24: 35-42.

FAO, 2013. Rice market monitor, Volume 16, Issue 4. Food and Agriculture Organization of the United Nations. http://www.fao.org/fileadmin/templates/ est/COMM MARKETS MONITORING/Rice/ Images/RMM-RMM-Nov13.pdf

FAO, 1998. Animal feed resources information system, $8^{\text {th }}$ edition. From the original book named Tropical Feeds by Bo GoÈhl Đ database by Andrew Speedy and Nick Waltham, FAO, Rome.

Haefele, S.M., Konboon, Y., Wongboon, W., Amarante, S. and Maarifat, A.A., 2011. Effects and fate of biochar from rice residues in rice-based systems. Field Crops Res., 121: 430-440. https://doi. org/10.1016/j.fcr.2011.01.014

Han, Y.W., 1975. Microbial fermentation of rice straw: Nutritive composition and in vitro digestibility of the fermentation products. Appl. environ. Microbiol., 29: 510-514.

Kim, W., Yahaya, M.S. and Goto, M., 2005. Effects of steam explosion on the chemical composition and rumen degradability of rice (Oryza sativa L.) straw. Grassland Sci., 51: 139-144. https://doi. org/10.1111/j.1744-697X.2005.00019.x

Lacefield, G., 2013. Alfalfa. University of Kentucky. www.uky.edu/ag/CCD/introsheets/alfalfa.pdf

Li, B., Gao, X., Sun, Q. and Chen, K., 2013. Enzymatic hydrolysis of rice straw based on 3, 5-dinitrosalicylic acid method. Trans. Chinese Soc. Agric. Machin.,
44: 106-112.

Liu, J.X. and Ørskov, E.R., 2000. Cellulase treatment of untreated and steam pre-treated rice straw-effect on in vitro fermentation characteristics. Anim. Feed Sci. Technol., 88: 189-200. https://doi.org/10.1016/ S0377-8401(00)00218-2

Liu, J.X., Orskov, E.R. and Chen, X.B., 1999. Optimization of steam treatment as a method for upgrading rice straw as feeds. Anim. Feed Sci. Technol., 76: 345-357. https://doi.org/10.1016/ S0377-8401(98)00196-5

McDougall, E.I., 1948. Studies of ruminant saliva. I. The composition and output of sheep's saliva. Biochem. J., 43: 99-109. https://doi.org/10.1042/ bj0430099

McMahon, L.R., Majak, W., McAllister, T.A., Hall, J.W., Jones, G.A., Popp, J.D. and Cheng, K.J., 1999. Effect of sainfoin on in vitro digestion of fresh alfalfa and bloat in steers. Can. J. Anim. Sci., 79: 203-212. https://doi.org/10.4141/A98-074

Naeem, M., Rajput N., Zhang, L., Zhuang, S., Yan, R. and Wang, T., 2014. Utilization of steam treated agricultural by product as ruminant feed. Pak. J. agric. Sci., 51: 229-234.

Sarnklong, C., Cone, J.W., Pellikaan, W. and Hendriks, W.H., 2010. Utilization of rice straw and different treatments to improve its feed value for ruminants: A review. Asian-Aust. J. Anim. Sci., 23: 680-692.

Tilley, J.M.A. and Terry, R.A., 1963. A two stage technique for the in vitro digestion of forage crops. J. B. Grassl. Soc., 18: 104-111. https://doi. org/10.1111/j.1365-2494.1963.tb00335.x

Toussaint, B., Excoffer, G. and Vignon, M.R. 1991. Effect of steam explosion treatment on the physicochemical characteristics and enzymic hydrolysis of poplar cell wall components. Feed Sci. Technol., 32: 235-242. https://doi.org/10.1016/03778401(91)90028-Q

Trach, N.X., 1998. The need for improved utilization of rice straw as feed for ruminants in Vietnam: An overview. Livest. Res. Rural Dev., 10: 2.

Viola, E., Zimbardi, F., Cardinale, M., Cardinale, G., Braccio, G. and Gambacorta, E., 2008. Processing cereal straws by steam explosion in a pilot plant to enhance digestibility in ruminants. Bioresour. Tech., 99: 681-689. https://doi.org/10.1016/j. biortech.2007.02.001

Zhu, W., Fu, Y., Wang, B., Wang, C., Ye, J.A., Wu, Y.M. and Liu, J.X., 2013. Effects of dietary forage sources on rumen microbial protein synthesis and milk performance in early lactating dairy cows. $J$. Dairy Sci., 96: 1727-1734. https://doi.org/10.3168/ jds.2012-5756 